\title{
DIE KERKLIKE STIMULASIE VAN EIETYDSE TRANSFORMASIEPROSESSE, EN DIE GELEENTHEID WAT DÍT AAN NYWERHEIDSBEDIENING BIED
}

\author{
Authors: \\ Michau Müller ${ }^{1}$ \\ Hennie J.C. Pieterse ${ }^{1}$

\begin{abstract}
Affiliations:
${ }^{1}$ Department Practical

Theology, University of

South Africa, South Africa
\end{abstract}

\section{Correspondence to:} \\ Michau Müller \\ email: \\ dokmike@telkomsa.net \\ Postal address: \\ PO Box 5987, Walmer, \\ Port Elizabeth 6065, \\ South Africa
}

\section{Keywords:}

World Council of

Churches; transformation

processes; church

renewal; industrial

mission; stimulation of

modern transformation

\section{Dates:}

Received: 29 June 2010

Accepted: 22 Aug. 2010

Published: 22 Nov. 2010

How to cite this article: Müller, M. \& Pieterse, H.J.C., 2010, ‘Die kerklike stimulasie van eietydse transformasieprosesse, en die geleentheid wat dít aan nywerheidsbediening bied', HTS Teologiese Studies/Theological Studies 66(2), Art. \#903, 5 pages. DOI: 10.4102/hts.v66i2.903

\section{This article is available} at:

http://www.hts.org.za

\section{Note:}

Hennie J.C. Pieterse is

Professor Emeritus in the Department of Practical Theology at the University of South Africa, Pretoria.

\section{(c) 2010. The Authors.} Licensee: OpenJournals Publishing. This work is licensed under the Creative Commons Attribution License.

\section{ABSTRACT}

The stimulation of the modern transformation processes by the church and the opportunity this presents to industrial mission

The church had reacted to both political and industrial change. Localised theology was the answer to a restricted political dispensation, and the final result was the application of liberation theology. The Kairos Document, the Evangelical Witness, the Belhar Confession and Church and Society express the different churches' viewpoints about the apartheid regime. This contextual focus on the same political dispensation unleashed church influence during the establishment of a national democratic dispensation. The different efforts to deal with industrial change by means of church renewal have finally paved the way for the development of a new industrial mission, vision and approach. This has resulted in the forming of an interchurch industrial organisation, and far-reaching possibilities within the industrial environment.

\section{INLEIDING}

In die eerste artikel is as medewerker van Praktiese Teologie [Unisa] (Müller \& Pieterse 2008:140161) daarop gewys dat die eietydse transformasieprosesse grootliks deur die industriële en politieke veranderinge gestimuleer is. Die kerk was nêrens in die beplanning en bedryf van die gebeure betrokke nie, maar het slegs daarop gereageer.

Vanuit hierdie kerklik-teologiese reaksie volg ' $n$ interne stimulasieproses wat weinig invloed op die eksterne transformasiegebeure uitoefen. Die situasie laat ontstaan nogtans talle vrae oor kerklike optrede in die sosio-politieke omgewing (Meiring 1983:295-299). Dit móés volg, want godsdiens en spiritualiteit speel op sowel politieke as industriële gebied 'n belangrike rol (vgl. Westgate 1996; Hinterkopf 1998).

Hierdie realiteit het ' $n$ effek op nywerheidsbediening, en daarom kry albei gebiede vervolgens aandag. Die vraag wat dus in hierdie artikel hanteer word, is watter ontwikkelinge in die industriële, politieke en teologiese omgewing ' $n$ invloed op die verandering van die eng apartheidstelsel in Suid-Afrika gehad het, en hoe dit die kerk se nywerheidsbediening uiteindelik beïnvloed het.

\section{ONTWIKKELING VAN SOSIAAL-POLITIEKE KERKLIKE FOKUS}

In Afrika het die bevrydingstryd die kerklike kritiek op kolonialisme en imperialisme verhewig (vgl. Sundkler 1960; Neill 1966). Van daaruit, het 'n eie Afrika-teologie teen die sosio-politieke misstande tot stand gekom (vgl. Torres \& Fabella 1978). Veral die Wêreldraad van Kerke (WRK) se werklikheidsbetrokkenheid het 'n sterk ekumeniese aksie aangevoor, wat uiteindelik bevrydingsteologie ondersteun het. Verskillende invloede gee hiertoe aanleiding.

Die kerk se inagneming van wêreldbeweginge het dekades lank tot kerklike hersieninge aanleiding gegee (vgl. Ubbink 1968:5). Die 18de-eeuse verligte teologiese denke stimuleer egter ' $n$ nuwe vorm van sosiale kritiek wat die saligmakende geloof met ' $n$ wêreldgerigte moralitieit vervang. Daarmee is die eties-sosiale plig van die Christelike kerk, tot sosiale hervorming gedwing (vgl. Heron 1980; Welch 1985). Met die sinkronisasie van die filosofiese, ideologiese en teologiese bevrydingskonsepte word 'n sterker klem op revolusie as op reformasie geplaas (Mackintosh 1969:147-150 vgl. Heyns 1975). Kerklike aktualiteit regverdig vervolgens deelname aan revolusies (vgl. Moltman 1969). Daarmee word revolusie, as bevryding vanuit onderdrukking, ook in die teologie belangrik ten einde verandering (vgl. De Ru 1974), en die verwerping van onaanvaarbare sosio-ekonomiese en politieke stelsels te verseker (vgl. Metz 1969; Gutiérrez 1975). Die proses vestig eventueel binne die WRK 'n Neo-Marxistiese bevrydingskonsep (Vorster 1984:34-35)

Die WRK se ekumeniese teologie is deur verskillende kerklik-teologiese aksente beïnvloed. Die Ortodokse kerke se uitreik na die Westerse kerke sou die belang van wêreldbedreiging vir die kerk beklemtoon. Die enigste bestaande verweer was 'n kerklike wêreldvisie waarin teologiese stagnasie met behulp van ideologiese stimulasie deurbreek moes word. Tydens die New-Delhi-byeenkoms van die WRK (vgl. WRK 1961) skep die fokus op sekulêr-politieke vraagstukke 'n groter ontvanklikheid vir NeoMarxistiese idees, wat uiteindelik tot ' $n$ Christelik-Marxistiese dialoog lei. Op grond hiervan word die sosio-politieke vergrype van sosialistiese lande geignoreer en Westerse politieke gebruike gekritiseer (Vermaat 1989:9-25, 95-103). Die Uppsala-byeenkoms (vgl. WRK 1968) konsentreer direk op die maatskappy waarna die WRK (vgl. WRK 1973) geregverdigde geweld as ' $n$ middel vir die verkryging van sosiale geregtigheid beskou en veral rassisme veroordeel (vgl. WRK 1975). Die nuwe politieketeologiese perspektiewe oor sosio-ekonomiese wantoestande in Suid-Amerika en Afrika bevorder bevrydingsaksies, wat die vestiging van 'n politieke teologie stimuleer (vgl. Lefever 1979; Koberstein 1982). Wat rassisme betref, val die soeklig ook op Suid-Afrika (Vermaat 1989:65-76). 
Met die nuwe sosiale fokus in die teologie rig veral vyf gebeure die kerklike hantering van die politieke bedeling.

Eerstens is die kerk-samelewing-verhouding hersien. Die 'Life and Work'-konferensie in Oxford in 1937 se bewoënheid oor sosiale wantoestande plaas 'n nuwe ekumeniese klem op eietydse wêreldgebeure (Visser 't Hooft 1974:20-23). Die tweede Vatikaanse raad (Vatikaan 11) gee aandag aan sosiale wantoestande (Inter Mirifica) en vra vir pastorale bewoënheid daaroor (Christus Dominus) en kerklike betrokkenheid daarin (Ad Gentes). Daarmee is ' $n$ kerklike wêreldbetrokkenheid binne die samelewingsnood aangevoor (vgl. Abbot 1972). Die WRK vereis dat sosio-ekonomiese geregtigheid die kerk se samelewingsbetrokkenheid rig en die negatiewe invloede van regerings temper (vgl. WRK 1983)

Tweedens is die Skrifgesag ondermyn. Vatikaan 11 se 'Church Message to the World' handhaaf soveel Skriftwispunte (Tatlow 1967:406-411) dat 'n sosiaal-politieke Skrifinterpretasie en omstrede wêreldbetrokkenheid die teologie oorheers (Van Elderen 1990:20-54). Sosiaal-politieke situasies word daarmee die bepalende faktor in die WRK (vgl. WRK 1971:9-17).

Derdens sou veranderde aksente oor die soteriologie volg. Die band wat Vatikaan II tussen die misterie van die verlossing en wêreldverandering lê (Mysteruim Salutis), verskuif die soteriologie vanaf Christus se persoonlike verlossingswerk na wêreldherstel (König 1975:37-38). Daarmee kry die bevrydingsteologie 'n spirituele dinamiek (vgl. Gutiérrez 1975) en word 'n nuwe hoopdimensie as antwoord op sosiaal-politieke wantoestande verkondig (vgl. Metz 1969; Moltmann 1973.) Aan die einde is die soteriologie finaal aan politieke verlossing verbind (Vermaat 1989:5-6)

Vierdens sou ' $\mathrm{n}$ andersoortige missiologiese strewe gevestig word. Sosiaal-politieke bevryding noodsaak 'n ordelike geloofseenheid asook teologiese eenstemmigheid. Slegs só kan wêreldkerstening verseker word. Die proses vereis egter erkenning van en dialoog met die nie-Christelike godsdienste, asook 'n sosiale bewoënheid oor nie-gekerstende volkere. Slegs kerklike eenheid kan groter kerklike invloed in wêreldgeregtigheid verseker (vgl. Visser 't Hooft 1968). Met die denkproses is die kerstening van die individu tot sosiaalpolitieke bevryding verhef (Van Elderen 1990:17-20).

Laastens sou hierdie teologiese verskuiwings ' $n$ meer eensydige politieke oriëntasie meebring. Dit verleen 'n politieke dimensie aan die WRK se kerk-staat-verhouding, en vestig die 'struggle' as ' $\mathrm{n}$ geregverdigde metode vir die verkryging van vryheid en geregtigheid (vgl. WRK 1981). Dit gee aanleiding tot die veroordeling van kapitalisme, wat as die hoofoorsaak van alle sosio-kulturele, ekonomiese en politieke vergrype gebrandmerk word. Daarteenoor word die neo-Marxisme se sosiale geregtigheid as die opheffing van politieke onderdrukking, die bestryding van rassisme, en die bevordering van menseregte gepropageer (Vermaat 1989:9-26, 61-64). Hiermee tree ' $n$ NeoMarxistiese politieke teologie na vore (vgl. Voster 1984; Snyman 1988) wat juis radikale teologiese veranderingsmodelle sou aanvoor.

\section{VESTIGING VAN TEOLOGIESE TRANSFORMASIEMODELLE}

Die vestiging van veranderingsmodelle gee aan die WRK se benadering die nodige skriftuurlike en teologiese omskrywing. Hieruit ontwikkel 'n kontekstuele fokus wat ' $n$ teelaarde vir die bevrydingsteologie sou bied. Ten einde die eietydse opset teologies te hanteer, word die Bybel sodanig in alle lewenskontekste geplaas dat die fokus eventueel die Bybelinterpretasie bepaal (vgl. Luzbetak 1981; Mpumlwana 1993:5-18). Die WRK se strewe na kontekstualiteit verbind die Bybelteks egter hoofsaaklik met die sosio-kulturele konteks, wat direk tot 'n situasiegerigte Bybeluitleg lei (Blaser 1980:202-222). Daardeur word kontekstuele en aktuele teologie (Waldenfells 1987:224-230) asook gelokaliseerde teologie (Pillay 1984:7-13), sinonieme. Verinheemsing en inkulturasie rig die fokus verder op sosiale wantoestande (Piskaty 1983:295-300), en word ekumenies bevorder. Die eindproduk is ' $n$ bevrydingsteologiese benadering wat die bevryding van die lydendes finaal moet verseker (vgl. Boesak 1977). Die fokus op rassisme (vgl. WRK 1969, 1975) inspireer die Pan African Christian Leadership Assembly (PACLA) in Nairobi (tydens 1976), en die South African Christian Leadership Assembly (SACLA) in Pretoria (tydens 1979) om die aktualisering van 'n gekontekstualiseerde boodskap in Suid-Afrika te vestig.

Hierdie kontekstuele fokus kry gestalte in die bevrydingsteologie van die Latyns-Amerikaanse worsteling teen klasseoorheersing, die swart teologiese weerstand teen rasseskeiding, en die feministiese teologie se verwerping van chauvinisme (Maimela 1986:176). In die proses sou God as die bevryder van die onderdrukte, en die herstel van menseregte, ' $n$ belangrike motief word (vgl. Rousseau 1975). Nuwe etiese norme is egter noodsaaklik vir politieke vernuwing, omdat dit sosiale gebreke in 'n ongelyke wêreldbedeling moet regstel (Jones 1984:9).

$\mathrm{Na}$ aanleiding van die WRK se 15-punt-resolusie insake rasse-aangeleenthede (vgl. WRK 1975), en die stigting van die 'Program to Combat Racism' (PCR), kom die Suid-Afrikaanse politieke beleid (apartheid) direk op die agendas van die WRK en die Cottesloe-beraad (vgl. Lückhoff 1978). Die strewe na sosiale geregtigheid, die opheffing van onderdrukking, en die bevryding van die onderdruktes sou die binnelandse 'struggle' rugsteun (vgl. Boesak 1977), en ook die hoop op 'n nuwe politieke bedeling in Suid-Afrika stimuleer (vgl. Buthelezi 1973; Buti 1979).

Hierdie proses sou in die binnelandse kerklik-teologiese hantering van politieke transformasie uitkristalliseer en so die weg vir 'n nuwe kerklike fokus op nywerheidsbediening in ' $n$ demokratiese Suid-Afrika help baan.

\section{KERKLIKE HANTERING VAN TRANSFORMASIE}

Die binnelandse kerklike hantering van politieke transformasie handhaaf enersyds ' $n$ konstante betrokkenheid en andersyds 'n ekumeniese gerigtheid.

Sedert die vestiging van die Christelike kerk in Suid-Afrika, het die kerk bygebly met die ingewikkelde binnelandse sosiopolitieke ontwikkelinge. Kerklike leiers het deurlopend ' $n$ bydrae tot die politieke hantering van die rassevraagstuk gelewer (vgl. Meiring 1983). Hierdie betrokkenheid het uiteindelik daartoe gelei dat die Afrikaanse kerke apartheid sou regverdig en steun, terwyl die swart en Engelse kerke dieselfde politieke beleid sou veroordeel en beveg (vgl. Geldenhuys 1982). Die vervreemding tussen Swart en Blanke en Engels- en Afrikaanssprekende kerke sou ook soveel onversoenbare standpunte tot gevolg hê, dat verwarring oor die kerklike hantering van politieke transformasie eventueel geskep is (vgl. Meiring 1983).

Wat die ekumeniese beweging betref, vestig die WRK se politieke-teologiese model ' $n$ eiesoortige kontekstuele benadering, wat direk tot ' $n$ situasiegerigte eksegese aanleiding gee (Blaser 1980:220-222). Daarmee word die teks in ' $n$ spesifieke konteks geplaas en gehou. Hierdie proses lei tot veral vier kerklik-teologiese dokumente waarin die hoofstroombinnelandse kerke 'n eiesoortige kontekstuele oplossing vir die binnelandse politieke situasie bied (vgl. Van Niekerk 1989). Dié vier dokumente is The Kairos Document: Challenge to the Church (hierna 'Kairos'); die Evangelical Witness in South Africa: A Critique of Evangelical Theology and Practice by Evangelicals Themselves (hierna 'Witness'); Die Belydenis 1986 van die Ned. 
Geref. Sendingkerk (hierna 'Belhar') en Kerk en Samelewing - ' $n$ Getuienis van die Ned. Geref Kerk (hierna 'Kerk en Samelewing'). Elke dokument lewer ' $n$ spesifieke bydrae binne politieke verandering .

Eerstens setel in elk van dié dokumente 'n eiesoortige konteks. 'Kairos' verwoord die houding van Europese wit mense teenoor inheemse Swart Afrikane, en 'Witness' die reaksie van die stedelike swart kerk op die moeilike sosio-ekonomiespolitieke omgewing. 'Belhar' praat uit die hoek van die Kleurlingsendingkerk, en 'Kerk en Samelewing' uit die oogpunt van die Blanke Afrikaanse Nederduitse Gereformeerde Kerk (NG Kerk). Ten spyte van ' $\mathrm{n}$ gebrek aan eenstemmigheid, verwoord dié dokumente nogtans ' $n$ duidelike kerklike stem oor dieselfde apartheid politieke bedeling (Van Niekerk 1989:2-3).

Tweedens word 'n gelokaliseerde teologie bedryf (Pillay 1984:713). Juis die WRK se strewe na ' $n$ nuwe politieke orde, bevryding van die onderdruktes, en respek vir menseregte gee aanleiding tot 'n duidelike fokus op politieke onreg (Tingle 1992:10-43). Vanuit hierdie uitgangspunt soek al vier kerklike modelle na ' $n$ politieke oplossing vir die bestaande onaanvaarbare regeringstelsels.

Derdens moet die kerk sy roeping binne die politieke omgewing uitleef. Die kerk en die staat bestaan in dieselfde politiekekulturele, maatskaplike en ekonomiese werklikhede, en daarom val die ganse lewensomgewing binne die trefwydte van die kerk se getuienis. Die kerk het dus ' $n$ verantwoordelikheid om politieke transformasie te help bevorder (Engelbrecht 1982:93).

Vierdens dwing ' $\mathrm{n}$ eie, binnelandse politieke revolusie die inheemse kerke om hul verskille en geskille by te lê. Daarmee is die uitdaging aanvaar dat die kerke die vernietigende plofkrag van rassediskriminasie moet ontlont voordat die land in totale anargie verval (Esterhuyse 1979:63-70).

Die geskiedenis van die kerk se rol in die vestiging van die eietydse Suid-Afrikaanse demokratiese bestel moet nog volledig te boek gestel word. Die kerk het egter duidelik op politieke transformasie gereageer. Daarin is grootliks ' $n$ kontekstuele en politieke teologiese fokus gehandhaaf. Hierdie positiewe ontwikkeling in kerk en teologie het vir die kerk die weg gebaan om ook ten opsigte van nywerheidsbediening ' $n$ nuwe koers in te slaan.

Die sterk fokus op die destydse sosio-politieke kwessies in die land het egter veroorsaak dat die industriële veranderinge (wat ook intussen plaasgevind het) nie die nodige aandag van die kerk gekry het nie. Die sosio-politieke ontwikkelinge en die kerk se hantering daarvan het egter 'n andersoortige kerklike hantering van die industriële transformasieproses vereis en sodoende ook gestimuleer.

\section{KERKLIKE HANTERING VAN INDUSTRIËLE TRANSFORMASIE}

Ten spyte van die kerk se beperkte rol in industriële veranderinge, het daar nogtans ' $n$ wêreldwye behoefte aan kerklike betrokkenheid ontwikkel, wat juis binnelands tot ' $\mathrm{n}$ kerklike ontledings-, vernuwings- en uitreikaksie sou aanleiding gee. Die kerklike ontleding van industriële verandering was egter ontoereikend. Daarom toon empiriese navorsing in verskillende nywerhede dat talle lidmate (meelewend én ander) die kerklike hantering van transformasie uiters negatief beleef (Müller 2005:125). Veral twee gebeure gee hiertoe aanleiding.

Eerstens veroorsaak verkeerde kerklik-teologiese insigte ' $n$ vorm van kerklike wêreldvervreemding. Die oordrewe vrees vir kerklike verwêreldliking ondermyn kerklike wêreldgerigtheid (Wentsel 1972, Deel 1:66-67). Die kerk se inwaartse fokus veroorsaak ook ' $n$ verlies aan kerklike funksionaliteit, en skep uiteindelik 'n kerklike identiteitskrisis (Gaum 2001:1). Kerklike isolasie volg juis omdat die micro-niveau (persoonlike lewe) nie by die meso-niveau (kerklike lewe) en die macro-niveau (sosiale lewe) geïntegreer word nie (Heitink 1993:94-95). Daarmee verloor die kerk sy invloed in die wêreld.

Tweedens lei negatiewe kerklike sieninge oor ekonomiese globalisering tot ' $\mathrm{n}$ negatiewe hantering daarvan. Dít gebeur omdat termverwarring tot sinnelose debatte hieroor aanleiding gee (Held 2000:22-43). Die vrese dat globalisering tot die vernietiging van kulturele identiteit aanleiding sal gee, reduseer die proses ook tot ' $n$ bedreiging (Hirsch 2001:1-7). Daarmee kry globalisering die skuld vir baie eietydse ekonomiese ellendes, en moet juis die kerk tot die vorming van ' $n$ mensvriendelike ekonomie en die vestiging van 'n bruikbare globale etiek bydra (vgl. Cahill 2002). Ten spyte van ' $n$ ontoereikende kerklike analise, word ' $n$ kerklike vernuwingsfokus nogtans daarmee aangevoor.

\section{AKTIVERING VAN KERKVERNUWINGSAKSIES}

Uit voormelde negatiwiteite oor ekonomiese globalisering vloei ook die positiewe insigte dat globalisering wêreldevangelisasie kan bevorder (vgl. Araujo 2000; Sogaard 2004). Daarby kan slegs kerklike vernuwing die nodige kerklike oorlewing verseker (vgl. Farley 1997; Haase 2004; Thwaites 2002). Die noodsaaklikheid vir oorlewing gee juis aanleiding tot veral twee tersaaklike kerklike vernuwingsmodelle, wat kortliks aangestip word.

In die eerste model gaan dit om vernuwing deur middel van vervanging. Die negatiewe invloede van die postmoderne gees vra vir die vestiging van ' $n$ kerklike model wat sinvol daarby kan aanpas (vgl. Sweet 1999). Die situasie vereis dat 'n nuwe soort kerklike bediening gevestig moet word, want die oue is afgeskryf, uitgeput en uitgedien (McLaren 1998:14). Slegs die hersiening van kerklike metodes, strukture, stelsels en gebruike kan groter kerklike beweeglikheid verseker (George 1992:37) en die ondermyning van tradisiegebondenheid oorbrug (vgl. McLaren \& Campolo 2003). Vir kerklike groei, moet die status quo dus opgehef word sodat charismatiese leiers ' $n$ dinamiese naamsverandering, ' $n$ nuwe bedieningsfokus, en ' $n$ aanskoulike gebedsforum kan vestig. Verder moet moderne elektroniese hulpmiddele die woordverkondiging aanskoulik maak; moet die tiendebeginsel nuwe projekte finansier, en moet die Heilige Gees genoeg ruimte gegun word sodat individuele talente kan ontwikkel (Wagner 1998:17-25). In die proses word alles wat die kerk laat kwyn, uitgerangeer (McLaren 1998:14).

Met die tweede model moet vernuwing deur middel van kerklike aanpassing geskied. In die proses word die waarde van vorige kerklike gebruike en teologiese inhoude erken, en word duidelik aanvaar dat God self sy kerk lei om veranderinge te verwerk (Naude 2005:17-35; Bosch 2005:177-180). Daarmee word 'n nuwe kerklike aktualiteit gevestig, omdat 'n eietydse teologie meer ruimte vir die bestaande belydenisinhoud en Bybelinterpretasies tydens transformasie bied (vgl. Burger 1995). Só waarborg kerklike aanpassings vernuwing, omdat die eeue oue kerklike ervaring deur middel van eietydse Woordverkondiging ' $n$ nuwe fokus kry (Naude 2005:33, 158160). Met hierdie aktualiteit behou die kerk sy belydenis en inhoud, sonder om sy wese, waarde, betekenis en siel te verloor.

Die vervangingsmodel hou die gevaar in dat uitgediende strukture onverstandig uitgefaseer kan word. Die vernuwingsmodel behou die basiese beginsels van die kerk, terwyl die bedieningsfasette daarvan by veranderde tye aangepas word. Juis laasgenoemde gerigtheid bied die ruimte vir die vestiging van ' $\mathrm{n}$ kerklikteologiese nywerheidsfokus.

\section{VESTIGING VAN NYWERHEIDSFOKUS}

Die eietydse Suid-Afrikaanse nywerheidsbediening ontwikkel vanuit veral drie daadwerklike kerklike optredes. 
Eerstens het ' $\mathrm{n}$ aantal kerke aan die Witwatersrand die Interdenominational Committee for Industrial Mission (ICIM) tot stand gebring, ten einde die kerklike werksaamhede in die myne beter te hanteer (IMSA 2003:1). Die Suid-Afrikaanse Raad van Kerke (SACC) het ICIM versoek om ' $n$ studiesessie oor nywerheidsbediening te hou, wat op die Wilgespruitkonferensie van 12-22 Junie 1967 en die dokument The Church's Industrial Mission (vgl. SACC 1967) uitgeloop het. Ten spyte van die sterk politieke ondertone oor armoede en onderdrukking, word nywerheidsbediening deurlopend as ' $\mathrm{n}$ verlengstuk van die kerklike bediening beskou (SACC 1967:10-15). Noue samewerking met maatskappye se maatskaplike-dienste(SACC 1967:30-32) en menslike-hulpbronne afdelings is egter noodsaaklik (SACC 1967:45-51). Daarby is tien beginsels vir nywerheidsbediening opgestel wat ' $\mathrm{n}$ interdenominasionele, diensbare en bruikbare bediening in die nywerheidsopset moet verseker. Die hoofbeginsel is egter deurlopend duidelik: Die Christendom moet die industriële omgewing verryk, en die Christelike kerk moet in die oplossing van gemeenskaplike probleme aktief wees (SACC 1967:25-27).

Tweedens onderneem die Suid- en Noord-Transvaalse Gesamentlike Kommissie vir Arbeidsbediening gerig op Transnet (GKAT) in 1993 'n navorsingsprojek waarin die topbestuur van 52 maatskappye oor die rol van die kerk in die nywerheidsomgewing getoets is. Die gepaardgaande empiriese bevindinge toon dat alle werknemers worstel om eietydse transformasie te verwerk, en dat godsdiens ' $n$ duidelike invloed te midde van al dié trauma het. Die kerk oorskat egter sy lidmate se rol in die nywerheid, en onderskat die nuwe intergodsdienstige invloede. Verder kan die normale gemeentelike bediening nie direk na die werkplek verskuif nie, en daarom moet ' $n$ interkerklike dimensie verseker dat daar by die 'Employment Assistance Program' (EAP) ingeskakel word. Slegs ' $n$ nutsmaatskappy kan ' $n$ wettige kontraktuele ooreenkoms tussen die kerk en maatskappye vestig, en ook verseker dat 'n duidelike kerklik-teologiese nywerheidsbedieningsbeleid dié werksaamhede rig (Müller 2005:328-333).

Derdens het die Instituut vir Sendingwetenskaplike Navorsing (ISWEN) die NG Kerk se Algemene Sinode (1994) van 'n nywerheidsbedieningsverslag voorsien (NG Kerk 1994:218224). Die verslag bepaal dat die verskillende streeksinodes die bestaande bedieningsprojekte moet uitbrei, nuwes aanvoor, en 'n ekumeniese bedieningstruktuur skep. 'n Nutsmaatskappy (artikel 21 van die Maatskappyewet) moet ook gestig word om 'n ekumeniese nywerheidsbediening te bedryf.

\section{ORGANISERING VAN NUWE BEDIENINGSTRUKTUUR}

Ná talle vergaderings is die nuwe nutsmaatskappy, Industrial Ministry in South Africa (IMSA), in Bloemfontein (tydens 2000) gestig. Die nuwe verkose direksie formuleer ' $n$ bedieningsbeleid (vgl. IMSA 2001) asook 'n bedryfshandleiding (vgl. IMSA 2003) wat ' $n$ gespesialiseerde kerklike fokus op die werkplek omskryf.

Albei IMSA-dokumente bepaal sekere bedryfsprosesse. IMSA is ' $n$ verlengstuk van die gemeentelike bediening, maar skakel vir die hantering van werkskonflik, rassespanning, gendermisverstande en werkgeoriënteerde krisisse by die EAPstelsel in. Die resultate van sosiale wantoestande (onder andere armoede, drank- en dwelmmisbruik) en gesondheidsprobleme (onder andere werkstres en vigs) word saam met die afdeling menslike hulpbronne hanteer. IMSA sal ook kerkrade, ringe en sinodes oor die beplanning van sodanige bedieningsprojekte adviseer.

\section{GEVOLGTREKKING}

Vanuit voorafgemelde is dit duidelik dat die kerk wél op die ingrypende sosiaal-politieke en industriële transformasieprosesse gereageer het. Die bevrydingsteologie het ' $\mathrm{n}$ belangrike rol gespeel in die beëindiging van apartheid, en die uiteindelike vestiging van ' $n$ nuwe demokratiese bestel in Suid-Afrika. Met kerklike vernuwing is op die industriële veranderinge reageer en maak sodoende ' $n$ nuwe fokus op nywerheidsbediening moontlik. Verder genoodsaak die transformasiegebeure op teologies-kerklike en industriële vlak in Suid-Afrika juis 'n nuwe benadering tot nywerheidsbediening. Vanuit al hierdie strominge is dan ook ' $n$ nuwe model ontwerp wat Arbeidsbediening spesifiek binne die Suid Afrikaanse bedeling kan rig en dien.

Met die laaste artikel word aandag aan die model gegee

\section{LITERATUURVERWYSINGS}

Abbott, W.M., 1972, The documents of the Vatican Council II, Chapman, London.

Araujo, A., 2000, Global missiology for the 21st century, Baker Academic, Grand Rapids.

Blaser, K.P., 1980, Kontextuelle Theologie als Ökumenisches Problem [Kontekstuele teologie as ekumeniese probleem], Suhrkamp, Frankfurt.

Boesak, A., 1977, Afscheid van de onschuld. Een sociaal-ethische studie over zwarte theologie en zwarte macht [Afskeid van die onskuld. 'n Sosiaal-etiese studie oor swart teologie en swart mag], Kok, Kampen.

Boesak, A, 1979, 'The Black Church and the struggle in SouthAfrica', The Ecumenical Review1980(32), 16-32.

Bosch, A., 2005, 'The pastoral and practical principles on which the churches in the New Testament were based, MTh thesis', Department of Practical Theology, University of Zululand.

Burger, C., 1995, Gemeentes in transito. Vernuwingsgeleenthede in 'n oorgangstyd, Lux Verbi, Kaapstad.,

Buthelezi, M., 1973, 'Theological grounds for an Ethic of Hope', in B. Moore (ed.), The Challenge of Black Theology in South Africa, pp. 147-156, John Knox Press, Atlanta.

Buti, S., 1979, 'The shadows of death and the future of hope in South Africa', Ecunews 24, n.p.

Cahill, L.S., 2002, 'Toward global ethics', Theological Studies 63(2), 324-344.

De Ru, G., 1974, De verleiding der revolutie [Die verleiding van rewolusie], Kok, Kampen.

Engelbrecht, B., 1982, Terwille van hierdie wêreld. Politiek en Christelike heilsbelewing in Suid-Afrika, Tafelberg, Kaapstad.

Esterhuyse, W.P., 1979, Afskeid van Apartheid, Tafelberg, Kaapstad.

Farley, E., 1997, 'Transforming a lukewarm church', Christian Century (3), 754-757.

Feil, E.\& Weth, R., 1969, Diskussion zur Theologie der Revolution [Bespreking van die teologie van die rewolusie], Munchen, Mainz.

Gaum, F., 2001, 'Beleef die kerk 'n identiteitskrisis?', Die Kerkbode 168(3), 1.

Geldenhuys, F.E.O'B, 1982, In die Stroomversnellings, Tafelberg, Kaapstad.

George, C.F., 1992, Prepare your Church for the Future, 6th edn., Fleming H. Revell, Grand Rapids.

Gutiérrez, G., 1975, A Theology of Liberation. History, Politics, and Salvation, 4th edn., SCM Press, London.

Haase, J. M., 2004, New wine into new wineskins (Luke 5:38). Church growth and revitalisation, UNISA, Pretoria.

Heitink, G., 1993, Praktische Theologie. Geschiedenis, theorie, handelsvelden [Praktiese Teologie. Geskiedenis, teorie, handelsvelde], Kok, Kampen.

Held, D. (ed.), 2000, Global Transformations, Stanford University Press, Stanford.

Heron, A.I.C., 1980, A Century of Protestant Theology, Westminister, Philadelphia.

Heyns, J.A., 1975, Teologie van die Revolusie, Tafelberg, Kaapstad.

Hinterkopf, E., 1998, Integrating spirituality in counselling: A manual for using the experiential focusing method, American Counselling Association, Alexandria. 
Hirsch, K., 2001, Humanizing Globalization: Globalization and Cultural Identity, Evangelische Akademie, Bad Boll.

Industrial Ministry in South Africa (IMSA), 2001, Industrial Ministry South Africa Operational Manual, IMSA, Cape Town.

Industrial Ministry in South Africa (IMSA), 2003, Industrial Ministry South Africa Operational Manual, IMSA, Cape Town

Jones, R.G., 1984, Groundwork of Christian Ethics, Epworth Press, London.

Koberstein, G. (Hrsg.), 1982, Nicaragua: Revolution und Christlicher Glaube [Nicaragua: Revolusie en die Christendom], Verlag Otto Lempeck, Frankfurt.

König, A., 1975, Ekumeniese teologie, Unisa, Pretoria

Lefever, E., 1979, Amsterdam to Nairobi. The World Council of Churches and the Third World, Ethics and Public Policy Center, Georgetown University, Georgetown.

Lückhoff, A.H., 1978, Cottesloe, Tafelberg, Kaapstad.

Luzbetak, L.J., 1981, 'Signs of progress in contextual methodology', Verbum SVD 22, 39-57.

Mackintosh, H.R., 1969, Types of Modern Theology, London, Fontana.

Maimela, S.S., 1986, Moderne tendense in die Teologie. Sistematiese Teologie, Studiegids 1, THB302, Unisa, Pretoria

McLaren, B.D., 1998, The Church on the other side. Doing Ministry in the Postmodern Matrix, Zondervan, Grand Rapids.

McLaren, B.D. \& Campolo, T., 2003, Adventures in missing the point. How the culture-contolled church neutered the Gospel, Zondervan, Grand Rapids.

Meiring, P.G.J., 1983, 'The church's contribution to change in South Africa', in D.J. van Vuuren, N.E. Wiehahn, J.A. Lombard \& N.J. Rhoodie (eds.), Change in South Africa, pp. 291-333, Butterworths, Durban.

Metz, J.B., 1969, 'Politische Theologie [Politieke Teolgoie]', in H. Peukert (Hrsg.), Diskussion zur Politischen Theologie, n.p., Kaiser/Grünewald, Munich/Mainz.

Moltmann, J., 1969, 'God in de Revolutie [God in die rewolusie]', Wending, Uitgawe Maart, geen bladsy.

Mpumlwana, M.M., 1993, 'The Road to Democracy. The Role of Contextual Theology', Journal of Theology for Southern Africa 85, 5-18.

Müller, M., 2005, ‘Transformasie en die Kerk. Die Kerklike hantering van eietydse Transformasie d.m.v. nywerheidsbediening', ongepubliseerde DTh-tesis, UNISA, Pretoria.

Müller, M. \& Pieterse, H.J.C., 2008 ‘Die hoofdryfkragte agter die eietydse transformasieprosesse soos dit die nywerheidsbediening beïnvloed', Praktiese Teologie in SuidAfrika 23(2), 140-161.

Nederduits Gereformeerde Kerk (NGK), 1994, Agenda, Algemene Sinode, deel 5, Nederduits Gereformeerde Kerk.

Naude, P., 2005, Geesgedrewe gelowiges. Christene met blydskap. Kerke wat groei, Lux Verbi, Kaapstad.

Neill, S.C., 1966, Colonialism and Christian Missions, Lutterworth, London.

Pillay, G.J., 1984, 'Contextualization of the Gospel in Southern Africa: The question of relevance', paper delivered at a conference on revival and reformation, North-West University, Potchefstroom, June, 1983.

Piskaty, K., 1983, 'The process of contextualization and its limits', Verbum SVD 24, 163-171.

Rousseau, H.W., 1975, Die wysgerige agtergrond van die Teologie van die Rewolusie, Universiteit van Stellenbosch, Stellenbosch.

South African Council of Churches (SACC), 1967, The Church's Industrial Mission, Wilgespruit Fellowship Centre, Johannesburg.

Snyman, J., 1988, Die etiek van die neo-Marxisme, PU vir CHO, Potchefstroom.

Sogaard, V., 2004, Evangelizing ourworld:insightsfrom global inquiry, Forum for World Evangelization, Thailand.
Sundkler, B.G.M., 1960, The Christian ministry in Africa, SCM, London.

Sweet, L., 1999, Soultsunami. Sink or Swim in New Millennium Culture, Zondervan, Grand Rapids.

Tatlow, T., 1967, 'The World Conference on Faith and Order', in R. Rouse \& S.C. Neill (eds.), A History of the Ecumenical Movement, pp. 405-444, SPCK, London.

Thwaites, J., 2002, Re-negotiating the church contract: the death and life of the $21^{\text {st }}$ century church, Paternoster Press, Carlisle.

Tingle, R., 1992, Revolution or Reconciliation. The Struggle in the Church in South Africa, Christian Study Centre, London.

Torres, S. \& Fabella, V. (eds), 1978, The emergent gospel: Theology from the Underside of History, Orbis, Maryknoll.

Ubbink, G., 1968, Kanttekeningen bij modern Christendom, Bosch \& Keuning, Baarn.

Van Elderen, M., 1990, Introducing the World Council of Churches, WCC, Geneva.

Van Niekerk, A.C.J., 1989, 'Kontekstualiteit in die Suid-Afrikaanse Sosiale-Etiek. 'n Vergelykende ondersoek na "The Kairos Document", die "Evangelical Witness", "Die Belydenis 1986" en "Kerk en samelewing",' ongepubliseerde DD-proefskrif, Departement Dogmatiek, Universiteit van Pretoria.

Vermaat, J.A.E., 1989, The World Council of Churches and Politics: 1975-1986, Freedom House, Boston.

Visser 't Hooft, W.A., 1968, Heel de kerk voor heel de wereld [Die hele kerk vir die hele wêreld], C.F. Callenbach, Nijkerk.

Visser 't Hooft, W.A., 1974, Has the Ecumenical Movement a Future, Christian Journals, Belfast.

Vorster, J.M. 1984, 'Die Neo-Marxistiese Politieke Teologie in Suid Afrika: 'n Gereformeerd-apologetiese studie', ongepuibliseerde Th.D. Potchefstroom, PU vir $\mathrm{CHO}$.

Wagner, C., 1998, The New Apostolic Churches, Regal Books, Ventura.

Waldenfells, H., 1987, 'Kontextuele Theologie [Kontekstuele Teologie]', in K. Müller \& T. Sundermeier (Hrsg.), Lexikon Missions-Theologischer Grundbegriffe, pp. 224-230, Dietrich Reimer, Berlin.

Welch, C., 1985, Protestant Thought in the Nineteenth Century, vol. 2, Yale University Press, New Haven.

Wentsel, B. 1972, De Koers van de Kerk in een Horizontalistisch Tijdperk [Die koers van die kerk in 'n horisontalistiese era], deel 1 \& 11, Kampen, Kok.

Wêreldraad van Kerke (WRK), 1961, The New Delhi Report. The Official Report of the Third Assembly of the World Council of Churches, SCM, London.

Wêreldraad van Kerke (WRK), 1968, The Uppsala Report. The Official Report of the Fourth Assembly of The World Council of Churches, WCC, Geneva.

Wêreldraad van Kerke (WRK), 1969, Statement of the WCC Consultation on Racism, WCC, Geneva.

Wêreldraad van Kerke (WRK), 1971, 'Faith and Order, Louvain 1971', Study Reports and Documents, Faith and Order, Paper No 59, WCC, Geneva.

Wêreldraad van Kerke (WRK), 1973, Violence, non-violence and the struggle for social justice, WCC, Geneva.

Wêreldraad van Kerke (WRK), 1975, 'Racism in Theology and Theology against Racism', report of a consultation organized by The Commission on Faith and Order and the Programme to Combat Racism, WCC, Geneva.

Wêreldraad van Kerke (WRK), 1981, Major Studies and Themes in the Ecumenical Movement, WCC, Geneva.

Westgate, C.E., 1996, 'Spiritual wellness and depression', Journal of Counseling and Development 75, 26-35. 